Dedicated to Corresponding Member of the Academy of Sciences of the Estonian SSR Oskar Kirret on the occasion of his 75 th birthday.

\title{
TRENDS IN THE THERMAL DEHYDRATION AND DECOMPOSITION REACTIONS OF RARE EARTH SULFATES
}

(Presented by M. Veiderma)

Thermal degradation of rare earth sulfate hydrates $\mathrm{Ln}_{2}\left(\mathrm{SO}_{4}\right)_{3} \cdot \mathrm{nH}_{2} \mathrm{O}$ $(\mathrm{n}=5,8 ; \mathrm{Ln}=\mathrm{Sc}, \mathrm{Y}, \mathrm{La}-\mathrm{Lu}$ excl. $\mathrm{Pm})$ has been studied in air by TG and DTA/DSC techniques. The trends observed in the dehydration temperatures and enthalpies as well as in the formation temperatures of the oxysulfate and oxide phases are discussed.

\section{Introduction}

Rare earth compounds represent an interesting case for thermoanalytical studies because their decomposition reactions usually occur in a wide temperature range from room temperature up to $2000 \mathrm{~K}$. Furthermore, due to the existence of isostructural series in the lanthanoid compounds, the thermoanalytical investigations can be usually extended to cover several lanthanoids including yttrium, making the conclusions more reliable.

The octahydrated sulfates of trivalent rare earths have been frequently studied by thermoanalytical methods. The early comprehensive studies by $W$. W. Wendlandt et al. using TG and DTA techniques ${ }^{[1-3}$ ] have been complemented by a simultaneous TG/DTA study by N. Bukovec et al.; the latter authors have also used DSC to determine the dehydration enthalpies [ $\left.{ }^{4}\right]$. Individual rare earth sulfate hydrates have been frequently investigated, too. For example, the most recent study employes high resolution luminescence spectroscopy to monitor the decomposition products of $\mathrm{Eu}_{2}\left(\mathrm{SO}_{4}\right)_{3} \cdot 8 \mathrm{H}_{2} \mathrm{O}$ during the TG experiments [5].

The decomposition schemes and trends observed in the studies involving al! lanthanoids have been discussed to some extent in $\left[{ }^{1-4}\right]$. In addition, A. N. Pokrovski and L. M. Kovba have given experimental data for the decomposition temperatures when anhydrous sulfates were used as starting materials [ $\left.{ }^{6}\right]$.

In order to get a more complete picture of the structure - thermal stability relationships for the rare earth sulfate and selenate hydrates, the present authors have undertaken a systematic study of the decomposition temperatures and trends. The dehydration reactions have been 
recently discussed in relation to the crystal structures [7]. Here we present the results concerning overall decomposition schemes and temperatures for the penta- and octahydrated sulfates.

\section{Experimental}

Rare earth sulfate penta- and octahydrates were crystallized from strong and medium sulfuric acid solutions, respectively; the crystals were characterized by X-ray diffraction. Samples ground to uniform grain size (100 mesh) were packed by a vibrating spatula into standard platinum crucibles (diam. $7 \mathrm{~mm}$, depth $19 \mathrm{~mm}$ ).

Simultaneous TG, TDG and DTA curves were recorded in the temperature range $300-1900 \mathrm{~K}$ on a Mettler TA-1 Thermoanalyzer using dynamic air atmosphere $\left(90 \mathrm{~cm}^{3} \mathrm{~min}^{-1}\right)$. Generally two sample weight/heating rate combinations were used: $200 \mathrm{mg} / 10 \mathrm{~K} \mathrm{~min}^{-1}$ (I) and $20 \mathrm{mg} / 2 \mathrm{~K} \mathrm{~min}^{-1}$ (II). The effect of sample holder geometry was studied in a third series of the experiments (III) by using the $20 \mathrm{mg} / 2 \mathrm{~K} \mathrm{~min}^{-1}$ sample rate combination but smaller crucibles (diam. $5 \mathrm{~mm}$, depth $5 \mathrm{~mm}$ ). All obtained curves were redrawn by the use of a computer programme taking care of buoyancy etc. corrections. In DTA measurements alumina was used as reference material and the calibrations were performed from 400 to $700 \mathrm{~K}$ with high-purity In, Sn, Cd and $\mathrm{Zn}$ metals.

Dehydration mechanism and enthalpy determinations were further checked by the use quasi-isothermal (MOM Derivatograph) and DSC (Perkin-Elmer DSC-1B and DSC-4) techniques, respectively.

\section{Results and discussion}

Thermal degradation in air consists of three main steps, viz. (1) dehydration, followed by formation of (2) oxysulfate and (3) oxide:

$$
\begin{gathered}
\mathrm{Ln}_{2}\left(\mathrm{SO}_{4}\right)_{3} \cdot \mathrm{nH}_{2} \mathrm{O}_{(s)} \rightarrow \mathrm{Ln}_{2}\left(\mathrm{SO}_{4}\right)_{3(s)}+\mathrm{nH}_{2} \mathrm{O}_{(\mathrm{g})} \\
\mathrm{Ln}_{2}\left(\mathrm{SO}_{4}\right)_{3(s)} \rightarrow \mathrm{Ln}_{2} \mathrm{O}_{2} \mathrm{SO}_{4(s)}+\mathrm{SO}_{3(g)} \\
\mathrm{Ln}_{2} \mathrm{O}_{2} \mathrm{SO}_{4(s)} \rightarrow \mathrm{Ln}_{2} \mathrm{O}_{3(s)}+\mathrm{SO}_{3(g)}
\end{gathered}
$$

As a representative example, the behaviour of $\mathrm{Ho}_{2}\left(\mathrm{SO}_{4}\right)_{3} \cdot 8 \mathrm{H}_{2} \mathrm{O}$ upon heating is depicted in Fig. 1.

Generally the observed decomposition temperatures in the penta- and octahydrate series depend. on the structure type and, within the isostructural compounds, on the rare earth ionic radii. Only cerium and scandium deviate slightly from this overall scheme; the trends and deviations thereof will be discussed in greater detail below.

Dehydration. The dehydration of the octahydrates proceeds in a single step with smaller samples (II), but when larger samples and higher heating rate (I) are employed, dehydration becomes a $2-3$ step process (cf. Fig. 1). The stability of the intermediate hydrates is obviously low because the plateaus do not correspond to phases of well-defined composition. This is in agreement with the report of T. Spasibenko who found by tensimetric studies several intermediate sulfate hydrates for trivalent cerium $\left[{ }^{8}\right]$.

The starting temperatures in the dehydration process seem to be rather uniformly around $380 \mathrm{~K}$, but the completion temperatures show descending trend as the size of the rare earth ion decreases (cf. Fig. 2). 


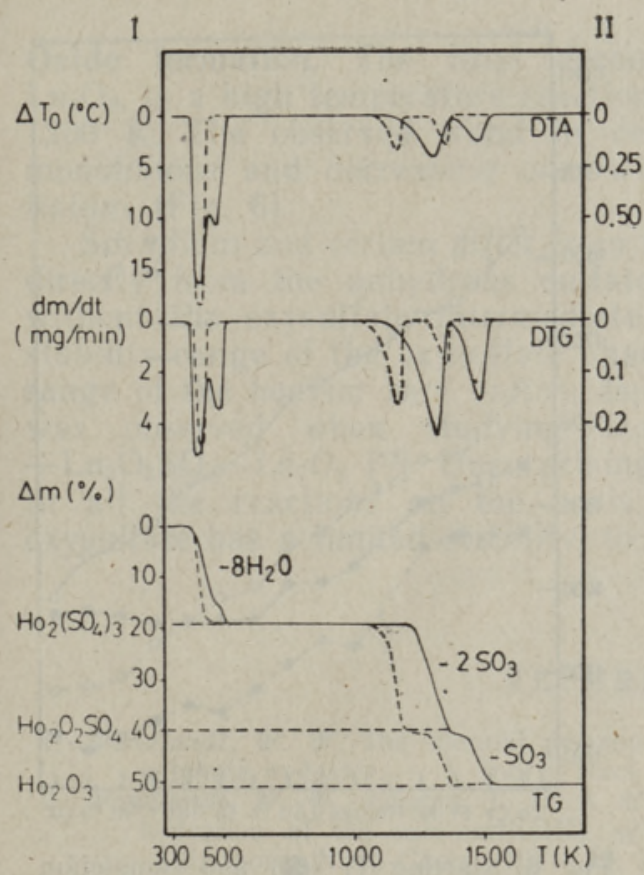

Fig. 1. TG, DTG and DTA curves for $\mathrm{Ho}_{2}\left(\mathrm{SO}_{4}\right)_{3} \cdot 8 \mathrm{H}_{2} \mathrm{O}$ recorded in air under two different conditions I (_- ) and II $(---)$. For experimental details, see the text.

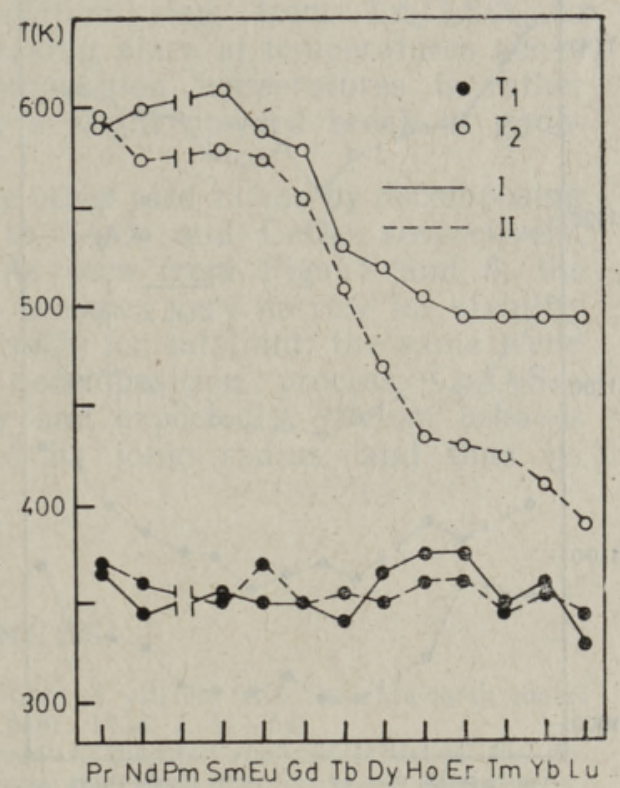

Fig. 2. Starting $T_{1}(-)$ and completion $\mathrm{T}_{2}(\mathrm{O})$ temperatures, measured in air under two conditions, for the dehydration reaction $\mathrm{Ln}_{2}\left(\mathrm{SO}_{4}\right)_{3} \cdot 8 \mathrm{H}_{2} \mathrm{O} \rightarrow \mathrm{Ln}_{2}\left(\mathrm{SO}_{4}\right)_{3}+$ $+8 \mathrm{H}_{2} \mathrm{O}_{(\mathrm{g})}$ in the isostructural series $\mathrm{Pr}-\mathrm{Lu}$.

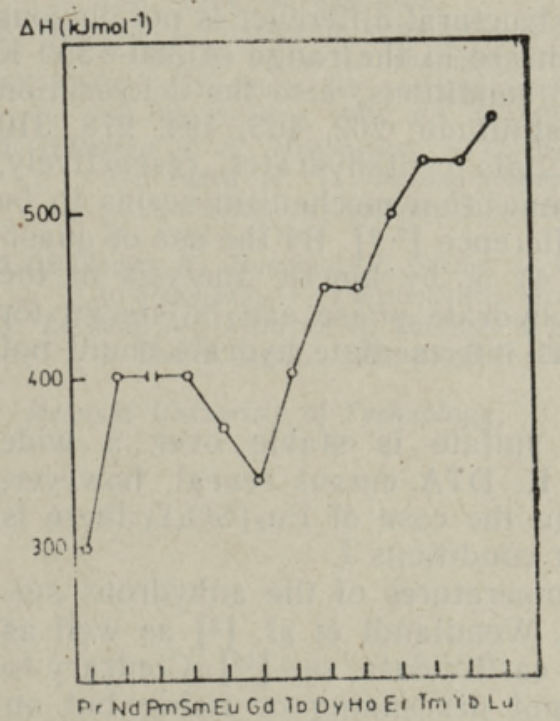

Fig. 3. Dehydration enthalpies $(\mathrm{kJ} / \mathrm{mol})$ for the octahydrates $\mathrm{Ln}_{2}\left(\mathrm{SO}_{4}\right)_{3} \cdot 8 \mathrm{H}_{2} \mathrm{O}$ $(\mathrm{Ln}=\mathrm{Pr}-\mathrm{Lu})$ measured under conditions. II.

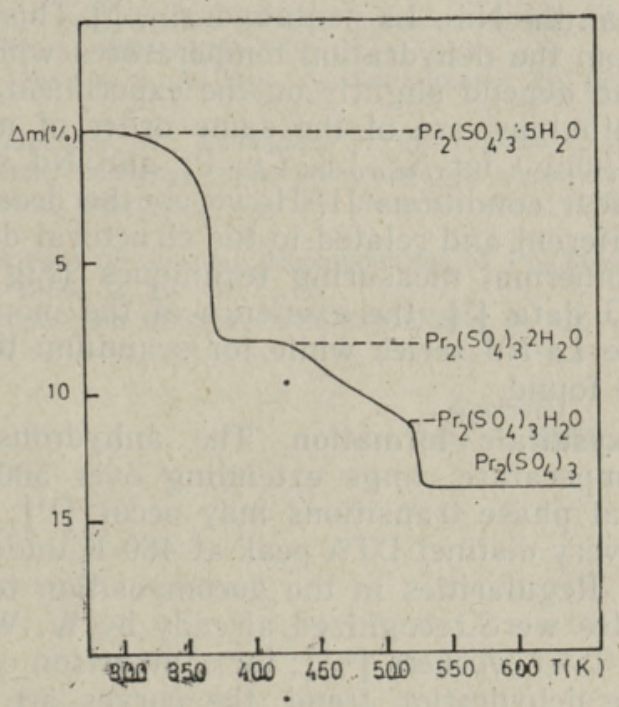

Fig. 4. Dehydration reactions of $\mathrm{Pr}_{2}\left(\mathrm{SO}_{4}\right)_{3} \cdot 5 \mathrm{H}_{2} \mathrm{O}$ measured in air under quasi-isothermal conditions with a $Q$-Derivatograph. Sample size is $200 \mathrm{mg}$. 


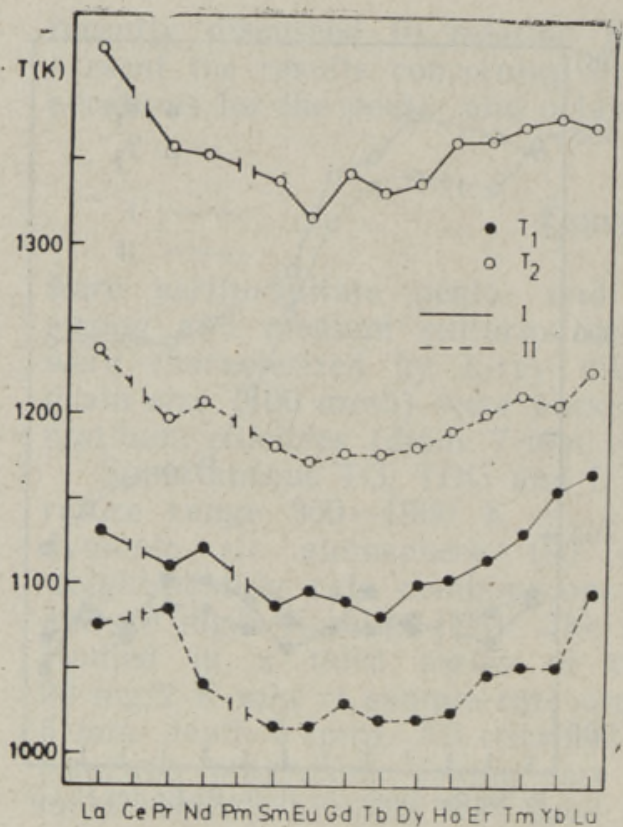

Fig. 5. Starting $\mathrm{T}_{1}$ $n_{2}\left(\mathrm{SO}_{4}\right) \mathrm{T}_{2}$ ) for the reaction lanthanoid series (La-Lu). Experimental conditions: I - - , II $-\ldots-$.

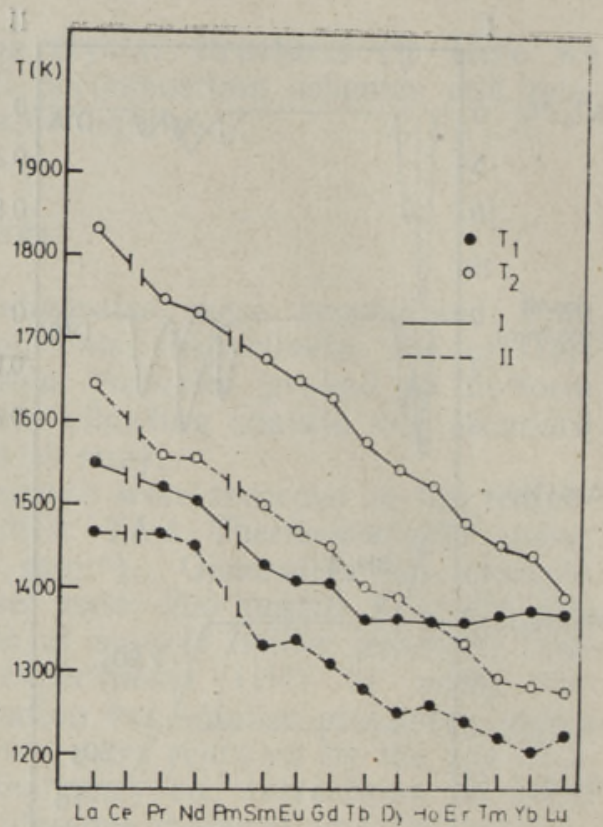

Fig. 6. Starting $T_{1}(0)$ and completion temperatures $\mathrm{T}_{2}(\mathrm{O})$ for the reaction $\mathrm{Ln}_{2} \mathrm{O}_{2} \mathrm{SO}_{4} \rightarrow \mathrm{Ln}_{2} \mathrm{O}_{3}$ in the lanthanoid series ( $\mathrm{La}-\mathrm{Lu})$. Experimental conditions:

Lanthanum and cerium sulfates deviate slightly from this general trend; this is obviously due to their different structure [ ${ }^{9}$. The dehydration enthalpies given in Fig. 3 show the opposite tendency with a maximum value for lutetium and a distinct break at gadolinium.

In the case of pentahydrates, scandium sulfate has a different structure than the $\mathrm{Nd}-\mathrm{La}$ pentahydrates [9]. This structural difference is not obvious from the dehydration temperatures which are in the range of $380-550 \mathrm{~K}$ and depend slightly on the experimental conditions; also the dehydration enthalpies are of the same order of magnitude: 202, 163, 194, 278, 310 $\mathrm{kJ} / \mathrm{mol}^{-1}$ for Sc, $\mathrm{La}, \mathrm{Ce}, \mathrm{Pr}$ and Nd sulfate pentahydrates, respectively, under conditions II. However, the decomposition mechanism seems to be different and related to the structural difference $\left[{ }^{7,9}\right]$. By the use of quasiisothermal measuring techniques (Fig. 4) or by kinetic analysis of the TG data $\left[{ }^{7}\right]$, the existence of the monohydrate phase can be shown for the La-Nd series while for scandium this intermediate hydrate could not be found.

Oxysulfate formation. The anhydrous sulfate is stable over a wide temperature range extending over $500 \mathrm{~K}$. DTA curves reveal, however, that phase transitions may occur [ $\left.{ }^{11}\right]$; in the case of $\mathrm{Eu}_{2}\left(\mathrm{SO}_{4}\right)_{3}$ there is a very distinct DTA peak at $480 \mathrm{~K}$ under conditions I.

Regularities in the decomposition temperatures of the anhydrous suifates were recognized already by W. W. Wendlandt et al. $\left[{ }^{2}\right]$ as well as by later workers $[4,6]$; for comparison of earlier data, see $\left[{ }^{10}\right]$. Contrary to the dehydration trend, the curves are not descending or rising but on the basis of present results they could be best described as U-shape curves (Fig. 5). Kinetic calculations for $\mathrm{Pr}_{2}\left(\mathrm{SO}_{4}\right)_{3}$ have indicated the decomposition to follow a linear law until $\alpha=0.5\left[{ }^{12}\right]$. 
Oxide formation. The final decomposition step, from $\mathrm{Ln}_{2} \mathrm{O}_{2} \mathrm{SO}_{4}$ to $\mathrm{Ln}_{2} \mathrm{O}_{3}$, is a high temperature reaction taking place at temperatures above $1200 \mathrm{~K}$. The observed trend in decomposition temperatures is rather monotonous and decreasing one, with a slight upward break at gadolinium (Fig. 6).

Scandium and cerium differ from the other rare earths by decomposing directly from the anhydrous sulfate to $\mathrm{Sc}_{2} \mathrm{O}_{3}$ and $\mathrm{CeO}_{2}$, respectively, without the oxysulfate intermediate. As seen from Figs 1 and 6 , the stability range of the oxysulfate phase becomes very narrow for stability range of the heavier rare earths, especially for lutetium; the same trend was observed when studying the decomposition process $\mathrm{Ln}_{2} \mathrm{O}_{2} \mathrm{~S}$ $-\mathrm{Ln}_{2} \mathrm{O}_{2} \mathrm{SO}_{4}-\mathrm{Ln}_{2} \mathrm{O}_{3}\left[{ }^{13}\right]$. Unsurprisingly and expectedly, yttrium behaves in all the reactions on the basis of its ionic radius, and thus its oxysulfate has a limited stability, too.

\section{REFERENCES}

1. Wendlandt, $W . W$. The thermal decomposition of yttrium and the rare-earth metal sulphate hydrates. - J. Inorg. Nucl. Chem., 1958, 7, 51-54.

2. Wendlandt, W. W., George, T. D. A differential thermal analysis study of the dehydration of the rare-earth(III) sulphate hydrates. The heats of dehydration. - J. Inorg. Nucl. Chem., 1961, 19, 245-250.

3. Nathains, M. W., Wendlandt, W. W. The thermal decomposition processes of the rare-earth sulphates. - J. Inorg. Nucl. Chem., 1962, 24, 869-879.

4. Bukovec, N., Bukovec, P., Siftar, J. Uber Salze und Doppelsalze der seltenen Erden. I. Die Thermoanalyse der hydratierten Sulfate. - Vestn. Slov. Kem. Drus., 1975, $22,5-17$.

5. Brittain, H. G. The thermal decomposition of $\mathrm{Eu}_{2}\left(\mathrm{SO}_{4}\right)_{3} 8 \mathrm{H}_{2} \mathrm{O}$ studied by high resolution luminescence spectroscopy. - J. Less-Common. Met., 1983, 93, 97102.

6. Покровский А. Н., Ковба Л. М. О термической устойчивости безводных сульфатов редкоземельных элементов. - Ж. неорган. хим., 1976, 21, 567-569.

7. Niinistö, L., Saikkonen, P., Niinistö, L. Thermal decomposition of rare earth sulfate and selenate hydrates. - Rare Earths Mod. Sci. Techn., 1982, 3, 257-263.

8. Спасибенко T. П. Исследование гидратов сульфата церия(III). - Ж. неорган хим., $1974,19,899-902$.

9. Niinistö, L. Inorganic complexes of the rare earths. - In: Systematics and the Properties of the Lanthanides. Dordrecht, 1983, 125-152.

10. Gmelin Handbuch der anorganischen Chemie, 8. Auflage, Systemnummer 39, Berlin-Heidelberg, 1981, C8, 40-42.

11. Зайщева Л. Л., Нльященко В. С., Конарев М. И., Коновалов Л. Н., Липис Л. В., Чеботарев Н. T. Физико-химические свойства кристаллогидратов сульфатов редкоземельных элементов тербиевой подгруппы. - Ж. неорган. хим., 1965 , $10,1761-1770$.

12. Bukovec, N., Bukovec, P., Siftar, J. Kinetics of thermal decomposition of $\mathrm{Pr}_{2}\left(\mathrm{SO}_{4}\right)_{3}$ to $\mathrm{Pr}_{2} \mathrm{O}_{2} \mathrm{SO}_{4}^{4}$. - Thermochim. Acta, $1980,35,85-91$.

13. Leskelä, M., Niinistö, L. Thermal decomposition of rare earth oxysulfates in air. J. Therm. Anal., 1980, 18, 307-314. 
L. NIINISTO, P. SAIKKONEN, R. SONNINEN

HARULDASTE MULDMETALLIDE SULFAATIDE TERMILISEST DEHUDRATATSIOONIST JA LAGUNEMISREAKTSIOONIDEST

On uuritud haruldaste muldmetallide sulfaatide hüdraatide $\mathrm{Ln}_{2}\left(\mathrm{SO}_{4}\right)_{3} \cdot \mathrm{nH}_{2} \mathrm{O} \quad(\mathrm{n}=5,8$; $\mathrm{Ln}=\mathrm{Sc}, \mathrm{Y}, \mathrm{La}-\mathrm{Lu}$, välja arvatud $\mathrm{Pm}$ ) termilist degradatsiooni ôhus TG ja DTA/DSC meetodiga ja analüüsitud dehüdratiseerimistemperatuuride ja -entalpiate ning oksiidsulfaatide ja oksiide sisaldavate faaside tekketemperatuuride määramise tulemusi.

Л. НИИНИСТЕ, П. САИККОНЕН, Р. СОННИНЕН

\section{О ТЕРМИЧЕСКОИ ДЕГИДРАТАЦИИ И РЕАКЦИЯХ РАЗЛОЖЕНИЯ СУЛЬФАТОВ РЕДКИХ ЗЕМЕЛЬ}

Исследована термическая деградация гидратов сульфатов редких земель $\mathrm{Ln}_{2}\left(\mathrm{SO}_{4}\right)_{3}$. - $n \mathrm{H}_{2} \mathrm{O} \quad(n=5,8 ; \mathrm{Ln}=\mathrm{Sc}, \mathrm{Y}, \mathrm{La}-\mathrm{Lu}$ за исключением $\mathrm{Pm})$ в воздухе методами $\mathrm{TG}$ и DTA/DSC. Обсуждены результаты определения температур и энтальпий их дегидратации, температур образования оксисульфатов и оксидсодержащих фаз. 